\title{
Considerations Of Vernacular Architect In Structures Case Study: Making Middle Structures In Simple Buildings In Kendari City Southeast Sulawesi Province
}

\author{
Muhammad Zakaria Umar', Sitti Rosyidah², Muhammad Arsyad ${ }^{3}$, La Ode \\ Amrul Hasan ${ }^{4}$, Ishak Kadir ${ }^{5}$ \\ \{muzakum.uho@gmail.com ${ }^{1}$, sitti_rosyidah@yahoo.com², m.arsyad.bic@gmail.com³ \\ ld.amrul@gmail.com ${ }^{4}$,ishak69kadir@gmail.com ${ }^{5}$ \} \\ 1,2,3,4,5 Department of Architecture, Faculty of Engineering, Halu Oleo University, \\ Bumi Hijau Campuss, H.E.A. Mokodompit Street, Andonohu, \\ Kendari, 93232, Indonesia
}

\begin{abstract}
Vernacular architecture is architecture without an architect.Educated architects highlight vernacular architects who tend to use low quality building materials, so academics worry about the quality of buildings. This research is important to know the structured method of vernacular architects who tend to be economical and can be synergized with the knowledge of educated architects, so that an economical structure is also found. This study is intended to assess the consideration of vernacular architects in making simple building structures. This study uses a case study method with a qualitative approach. Data collection is done by observation and interview. Data is analyzed by percentage. Based on the description above it can be concluded that the vernacular architect in making the middle structure of a simple building, as follows: in the first stage is careful consideration, in the second stage is a practical consideration, and in the third stage is an economic consideration.
\end{abstract}

Keywords : Vernacular Architects, Concideration, Middle Structures In Buildings.

\section{Introduction}

Indonesia has more than 13,600 islands. Indonesia has an impressive and amazing vernacular architecture. Vernacular architecture is described as a portrait of the development of human history, especially in the fields of architecture and buildings [1]. Vernacular architecture is architecture without an architect. Vernacular architecture has the following characteristics: 1) vernacular architects built by society, vernacular architecture used by local communities and without architects; 2) vernacular architecture built by construction workers and based on experience [2]; 3) vernacular architecture designed by ordinary audiences who do not take formal education, as well as; 4) making vernacular buildings based on trial and error and handed down from generation to generation [3]. On the other hand, vernacular architecture has advantages, as follows: 1) vernacular architecture responsive to the climate and its environmental needs; 2) vernacular architecture is more concerned with aspects of building functions; 3) vernacular architecture can accept change; 4) vernacular architecture using simple and practical construction. Economic factors should be considered in building planning. Vernacular architecture is intended to meet special needs that accommodate the economic values and cultural order of the local community [4]. Simple buildings in Indonesia 
are generally built without the help of a building expert and structure. The building is only made and based on the experience of local artisans [5].

Vernacular architecture is part of local culture and vernacular architecture has a soul, so it becomes a living architecture. Vernacular architecture also shows indigenous, tribal, peasant architecture and traditional architecture. Vernacular architecture is used as academic terminology. This is intended to categorize architecture outside the academic tradition. Construction of vernacular architecture is often carried out simultaneously at the construction site. This is done by builders, individuals and groups alike. Building users are involved in this process. The forms of vernacular buildings include floor plans, looks, and pieces are local patterns. Local patterns are inherited from generations through hundreds of years. This pattern does change, but it is very slow. New buildings on vernacular architecture come from cultural norms and building art that accumulates in them. Vernacular architecture is admired by many people. This is due to its amazing adaptation to the natural environment and adapted to the needs of the local community. Vernacular architecture is strongly influenced by globalization $[1]$.

Failure in the process of developing vernacular architecture can result in the fading of all concepts that have been developed by predecessors for years. Vernacular architecture is less scientific. Although vernacular architecture develops intuitively in a long time, it is actually very scientific with a valid concept. Vernacular architecture and local values are seen as part of the solution. Vernacular architecture developed through so many experiments and experiences. Vernacular architects continually use what is considered good and throw away bad things. Vernacular architecture is studied as a mine of knowledge. Vernacular architecture contains local wisdom [1]. Vernacular buildings are planned with consideration; quickly built, paying attention to humans as residents, taking into account the climate and the environment, building performance that is good and acceptable to the local community [6]. Vernacular architecture is inherent in the living system of its people, expressions and traditions of local life will produce space as a place for their activities. The form of vernacular architecture is considered as a scope of space and vernacular architecture serves as an expression of completion of the setting of places and customs [7]. Thus, vernacular architecture is planned, as follows: 1) based on local culture; 2) quickly built; 3) adapted to the needs of residents; 4) good building performance; 5) it is pleasing to the people.

Training programs for local artisans in the reconstruction of houses after the earthquake in Pasaman Regency, as follows: 1) local artisans mostly obtain carpentry for generations and do not have a basic knowledge in the field of structural engineering; 2) local artisans are called the spearhead of housing development in the community and should get more attention; and 3) this training is useful for local artisans to repair earthquake-damaged houses [8]. Local artisan needs to be upgraded. One of them is building knowledge of earthquakes, as follows: 1) local artisans tend not to be socialized with simple earthquake-safe houses; 2) the expertise of builders tends to be less uniform; 3) the competitiveness of builders tends to be low; 4) Builders' knowledge of the structure tends to be low and enough to follow orders from the project owner; 5) knowledge of earthquake resistant houses to construction groups needs to be transmitted [9].

Income describes the economic position of the household. If income increases, the physical condition of the house will also increase [10]. Houses and housing buildings must be strong to withstand all burdens. The building structure must meet the requirements of stability, balance, strength, aesthetics and economics [11]. In general, building construction must meet economic requirements. Economical means not wasteful, so that the cost of structure becomes efficient and effective [12]. The results showed that reinforcement of beams and residential 
columns can be made smaller reinforcement dimensions. This means that reinforcement installed in the field is safe to use, but can still be minimized. This is intended to be more economical without reducing the value of security [13]. Portland Cement brick is often used as wall material. Portland Cement brick is called the most economical wall material. After installation of brick, the wall is immediately given mortar. Installation of bricks must be flat, so the mortar has the same surface. This is intended to save costs [14]. Thus, economic principles are needed in buildings without reducing their security value.

In traditional societies houses are considered as micro-cosmic and macro-cosmic forms. The Macrocosm is divided into three parts, as follows: 1) the upper world is considered a sacred area and the place of the gods; 2) the middle world is considered a place of human habitation; 3) the underworld is considered a dirty area and inhabited by animals [15]. The structural system consists of three parts, as follows: 1) the bottom structure is called the basic structure and forms the building foundation; 2) middle structure including columns, beams, walls and floors; and 3) the upper structure is called an extension of the building above the middle structure [12]. The building structure consists of foundations, walls, columns, floor plates, and roof easel [16]. Thus the middle structure is also called the middle world. The middle structure consists of columns, beams, walls and floors.

In general, community housing in Kendari City tends to be designed and planned by vernacular architects. The vernacular architects are the spearhead of society in establishing housing in Kendari City. Buildings created by vernacular architects are pleasing to the people of Kendari, because the buildings created by vernacular architects are in accordance with the needs of the residents. The needs of residents are compromised by vernacular architects and building occupants, such as economic principles. Economic principles are manifested in architectural elements of buildings, such as landfill, floor rebates, iron reinforcement, concrete, mortar and so on. According to vernacular architects, the vernacular architectural method is appropriate and for academics tends to be less precise. Educated architects highlight vernacular architects tend to use low quality building materials, so academics worry about the quality of buildings. This research is important to know the structured method of economical vernacular architects and can be synergized with the knowledge of educated architects, so that an economical structure is also found. This study is intended to assess the consideration of vernacular architects in making simple building structures.

\section{Research Method}

This study uses a case study method with a qualitative approach. The choice of this method is based on the objectives of the study. This study uses the object of research to assess the consideration of vernacular architects in making simple building structures. Data collection is done by observation and interview. Observations were made to find research indicators. Interviews were conducted to assess the consideration of vernacular architects in making columns, upper perimeter beam, walls and floors (table 1).

Table 1. Data Requirements.

\begin{tabular}{|c|c|c|}
\hline Research purposes & Variable 1 & Variable II \\
\hline $\begin{array}{l}\text { This study is } \\
\text { intended to assess } \\
\text { the consideration of } \\
\text { vernacular architects } \\
\text { in making simple } \\
\text { building structures }\end{array}$ & $\begin{array}{l}\text { Columns, walls, beams } \\
\text { around the top and floors. } \\
\text { Careful consideration }\end{array}$ & $\begin{array}{l}\text { Columns, walls, upper } \\
\text { perimeter beam and floors. } \\
\text { Careful consideration } \\
\text { Practical considerations } \\
\text { Economic considerations } \\
\text { Assessing the consideration }\end{array}$ \\
\hline
\end{tabular}


Data Analysis Method. Data analysis can be done, as follows: 1) information is organized; 2) information and codefication learned; 3 ) the case and its context are described; 4) findings are interpreted; 5) findings are presented narratively; and 6) data are analyzed by percentage.

$$
\text { Assessment }=\frac{\text { Amount of consideration }}{\text { Amount of indicators }} \times 100 \%
$$

\section{Results and Discussion}

The assessment of vernacular architect's judgment in making the middle structure of a simple building obtained a total careful consideration of $1.59 \%$, a total practical consideration of $1.32 \%$ and a total economic consideration of $1.14 \%$ (table 2 ).

Table 2. Recapitulation of consideration.

\begin{tabular}{|c|c|c|c|c|c|}
\hline \multirow{2}{*}{ Consideration } & \multicolumn{4}{|c|}{ Middle Structure } & \multirow{2}{*}{$\begin{array}{l}\text { Tot. } \\
(\%)\end{array}$} \\
\hline & $\mathrm{A}(\%)$ & $\mathrm{B}(\%)$ & $\mathrm{C}(\%)$ & $\mathrm{D}(\%)$ & \\
\hline Careful & 0 & 0,55 & 0,5 & 0,54 & 1,59 \\
\hline Practical & 0,42 & 0,35 & 0,17 & 0,38 & 1,32 \\
\hline Economical & 0,59 & 0,12 & 0,34 & 0,09 & 1,14 \\
\hline
\end{tabular}

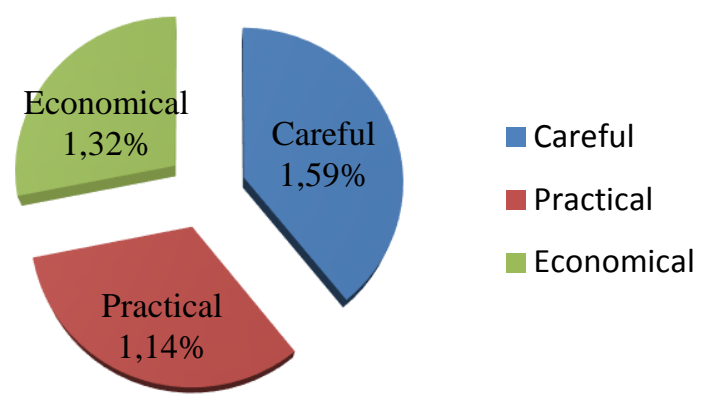

Fig. 1. Differences in the value of consideration of vernacular architects.

The assessment of vernacular architect's judgment in making the middle structure of a simple building obtained a higher value of careful consideration of $1.59 \%$ compared to a practical consideration of $1.32 \%$ and an economic consideration of $1.14 \%$ (figure 1 ). 


\subsection{Careful Considerations 1.59\%}

\subsubsection{Wall}

The walls were obtained by vernacular architects of careful consideration, as follows: (1) sand floor rebate material and plaster mortar were used by sand from the Pohara area. This type of sand includes both used as floor rebate and mortar material. Pohara Pair has the color characteristics of gray sand tend to be dark, rather coarse, and grained sand like sugar/salt; (2) wall plaster mortar is made with a composition of 1: 4 ( 1 cement: 4 sand). This composition results in a more fluffier mortar (not liquid); (3) the walls are splashed before the plaster. This is intended so that the wall is more integrated with the plaster mortar; (4) the walls are watered until wet. This is intended so that the wall is more integrated with the plaster mortar; (5) walls not watered during the rainy season. This is because the wall has been wet, so the wall does not need to be watered. Walls drenched with water are preferred in the dry season; (6) plaster mortar containers are needed when the walls are plastered. It is intended that the fallen mortar be used again, so that the mortar use is more efficient; (7) uneven walls are patched with mortar. This is intended so that the walls are flat and aesthetic; (8) plaster scouring board is used by forming a circle and used clockwise. This is intended so that the mortar is flat and aesthetic; (9) the process of wall plaster starts from the beam head around the bottom $(10 \mathrm{~cm})$ and continues to the surface of the lower perimeter head; 10) the wall not given a plaster mortar is located above the lower perimeter head. This is intended for the installation of ceramic floors; (11) mortar is applied to the wall and used a putty knife. Putty knife (Kape) is a tool to carry out the skim coat process. Two taps are pulled from the bottom up; (12) walls are made with a height of $3.00 \mathrm{~m}$ and $3.20 \mathrm{~m}$. The height of this wall is included in the installation of ceiling and house looks spacious; (13) the wall is measured from the head of the lower perimeter to the upper perimeter head. This measurement is called clean height; (14) walls are required to be straight. Straight walls are carried out by weighing (lot); (15) the wall is carefully weighed, so that the wall made by the vernacular architect is straight and elbow; (16) weighing has the principle that one rope and the other rope must touch each other. The contact of the one-tier rope and the second tier rope do not need to be too close. The straps must touch each other, so that the straight and elbow walls are obtained; (17) when the red stone is touched and rocked, the plaster should be stopped immediately. The process of wall plaster should wait for the dry mortar (about half a day) and can be continued with the use of plaster mortar. After that, the installation of red stone can be continued. A rocky wall is feared to collapse; (18) the wall also has the potential to collapse because the spacing between columns is short and the wall is above 3 meters high. The wider the distance of the wall, the stronger the bottom of the wall is. Whether or not the wall is broken is also influenced by sand material. The better the sand material, the mortar is also good. Sand from the Pohara area is very well used as a mortar material; (19) concrete vent holes installed with meterpas.

\subsubsection{Upper Perimeter Beam (Ring beam)}

The making of the upper perimeter beam (ring beam) is obtained by vernacular architects of careful consideration, as follows: (1) upper perimeter iron beams tie together with column iron. Upper beam iron is bent or tied; (2) the binding process is wrapped with concrete tie wire (benderat wire). 


\subsubsection{Floor}

Floor making is obtained by vernacular architects of careful consideration, as follows: (1) sand is spread over the pile. Sand is needed so that the soil does not come into direct contact with the mortar. The landfill does not blend with the mortar; (2) after carrying out the stockpiling process, the Nambo sand is spread over the pile. If the sand is not spread on top of the heap, the mortar will not bind to each other; (3) in the first stage, the ceramic floor is installed behind the entrans door. The tiled floor is placed in the order of the second row. The first reason is that there are remaining spaces that have not been installed with ceramics. The rest of the space is used as a circulation path for the workers. The second reason is because the foundation is not always made by building workers straight and elbow; (4) door leaves are difficult to close, shutters are difficult to close, sloping walls and floors are not elbows are the foundation factors are made not elbows. So the foundation must be made straight and elbow; 5) Ceramic floors need to be soaked before use. This is intended so that the ceramic floor seeps in and blends with the mortar; (6) ceramic floor is soaked until it sinks. Ceramic floors are soaked for 5-10 minutes; (7) ceramic floor mortar is made with a composition of 1: 4. This composition is needed by the tile floor because the floor is located below. The floor needs a good mortar composition because the floor is stepped on and the composition of the mortar dries quickly; (8) embankment sand (uruk) should be watered so that the mortar does not dry quickly. If the sand is not doused with water, the mortar is feared to quickly drop down. This resulted in the tile floor not sticking well; (9) mortar is $5 \mathrm{~cm}$ thick. This composition is needed because the floor is stepped on and the floor can glue well; (10) the size of the ceramic floor $40 \mathrm{~cm} \times 40 \mathrm{~cm}$ is often recommended by floor construction workers. This size is used so that the house seems spacious; (11) the characteristics of straight floors and elbows can be seen in the gap between floors (Nat) not close together; (12) ceramic floors are made with precision measurements. Floor tiles are $30 \mathrm{~cm}$ x $30 \mathrm{~cm}$ and $40 \times 40 \mathrm{~cm}$ in size. These ceramic floors are often used by vernacular architects. But in reality there are still shapes and sizes of tile floors that are not precise. The size of the tile is not precise, it is feared that the installation of the floor is not straight and elbow; (13) the lower perimeter beam and foundation are made not straight and elbow. These two things can result in the installation of the ceramic floor is not straight and elbow; (14) ceramic floor is installed by weighing (lot). This is intended to make the ceramic floor straight and elbow; (15) the bathroom floor is placed horizontally from the corner of the house. After that, the ceramic floor installation then follows the horizontal tile floor. Vertical floor tile installation starts from the second row angle. This is intended for a foothold to install ceramic tiles. Ceramic floors are installed horizontally and mounted parallel to the vertical tile floor. This is intended to be aesthetically pleasing and to minimize cutting of ceramic floors; 16) installation of ceramic walls takes precedence over ceramic floors. Ceramic floor adapts to ceramic walls. This is done so that the ceramic wall looks straight and elbow; (17) bathroom ceramic walls are installed from the corner of the bathroom. Bathroom floor tiles are used with a size of $30 \mathrm{~cm}$ x $30 \mathrm{~cm}$. The bathroom ceramic wall is $1.50 \mathrm{~m}$ high. The bathroom layer consists of landfill, sand, mortar (4 cm thick) and ceramic floor; (18) installation of ceramic floor is carried out weighing (lot);(19) the bathroom ceramic floor is installed under the lower head and about $3 \mathrm{~cm}$ thick. The bathroom tile floor is lowered $2 \mathrm{~cm}$ from the lower perimeter head. Kitchen tile floors are installed above the lower perimeter beam, so the hierarchical total floor becomes $5 \mathrm{~cm}$. This is what makes hierarchical on the bathroom floor and kitchen floor; (20) the kitchen and bathroom are limited by the lower perimeter head. The head of the lower perimeter beam is located closest to the bathroom floor. The lower perimeter beam is used as the door border.

\subsection{Practical Considerations $1.32 \%$}




\subsubsection{Coloumn}

Making columns obtained by vernacular architects practical considerations, as follows: (1) work tools make stirrup columns, as follows: reinforcement iron assemblers, stirrup iron assemblers, iron keys and iron scissors. Steel sheet assemblers and stirrup iron assemblers are made by vernacular architects themselves. Iron keys and iron scissors are available; (2) the column is given a mixture of concreting. Sand material is used from the Nambo area. This type of sand is gravel, so there is no need to use split stones; (3) Nambo sand types do not need to be sieved and are directly used as concrete material. This sand has the characteristics of red sand tend to be bright, the sand contains a lot of soil, gravel sand, and white gravel; (4) reinforced concrete columns used iron material. Iron is used with a length of $3.20 \mathrm{~m}$. After the floor is given concrete rebates and floors, then the column reinforcement length becomes 2.70 $\mathrm{m}$; (5) stirrup iron columns are assembled with six stirrup iron. Stirrup iron is installed with the principle closer to the lower perimeter beam/upper perimeter beam, then stirrup iron is installed at close range. Stirrup iron is installed remotely, if the stirrup iron is farther away with a lower perimeter beam / upper perimeter beam (the distance of stirrup iron). The closest stirrup distance is $17-20 \mathrm{~cm}$ and the furthest stirrup iron distance is $30-50 \mathrm{~cm}$.

\subsubsection{Wall}

Making walls is obtained by vernacular architects practical considerations, as follows: (1) if the rainy season the wall does not need to be splashed with water. This is because the wall has been wet. The walls are not splashed with water and are immediately given a plaster mortar; (2) wall plaster mortar is adjusted to the worker's height. This is done so that the plaster process is more effective; (3) after the wall is given a plaster mortar, the wall is leveled with wood. Wood is used with a flat surface; (4) plaster mortar is flattened with a polisher and splashed with water. Scouring board made of wood. This is intended to make the plaster mortar smooth and flat. Scouring boards are used by forming a circle and are used clockwise. The polishing tool is used on the right hand and the receiving board is held with the left hand; (5) red stone arranged with mortar. If the mortar hardens and blocks the plaster process, the mortar is crushed with a hammer; (6) the process of giving skim coat is done by, as follows: (a) if the plaster wall has been completed, then the process of giving a skim coat can be done. The walls are scrubbed and cleaned with putty knives or use cement bags; (b) two taps drawn from the bottom up; (c) after all the walls have been given a skim coat, the skim coat administration process is repeated again. This is intended so that the walls are smooth (specifically for the inner wall only); (d) the process of giving skim coat is carried out for three days; (e) the height of the weighing rope is adjusted to the height of the worker or one meter. This is intended to facilitate construction workers in the weighing process, (f) vernacular architects prefer to give thick mortar to the installation of red stone. The thicker the wall mortar, the faster the wall stands; $(\mathrm{g})$ one red stone and another red stone and a mortar made of $4-5 \mathrm{~cm}$ thick; (h) installation of sills together with wall mounting; (i) concrete vent holes are installed per two pieces and placed on the frame.

\subsubsection{Upper Perimeter Beam (Ring beam)}

The making of the upper perimeter beam (ringbalk) is obtained by the vernacular architect for practical consideration in the concretion of the upper perimeter beam, as follows: the upper perimeter beam is made with $1-2 \mathrm{~cm}$ thick, so that it can wrap the upper perimeter beam and wall. 


\subsubsection{Floor}

Floor making is obtained by vernacular architects for practical considerations, as follows: (1) ceramic floors are not installed on the second row. It is feared that the installation of the floor is not straight, because the foundation is not always straight; (2) ceramic floor soaked before use; (3) ceramic floor soaked in water in the lorry. This is done so that the installation of ceramic floors is faster; (4) ceramic floor is soaked until it sinks. This is intended so that the floor is more integrated with the mortar; (5) ceramic floor installed by weighing. Door height is measured from top and bottom. For example the height of the door is about two meters. The bottom of the door is added about $2 \mathrm{~cm}$. This is intended for the difference in size between the door leaf (bottom) and the tile floor. The door is measured around $101 \mathrm{~cm}$ above the corner of the wall (near the door). The wall is marked. The distance of $101 \mathrm{~cm}$ is weighed into the corners of the house. Weighing using a measuring hose; (6) the bathroom floor is weighed; (7) the layers of the bathroom floor consist of soil, sand, mortar (4 $\mathrm{cm}$ thick) and ceramic floor; (8) the kitchen and bathroom are limited by the lower perimeter head. The head of the lower perimeter beam is located closest to the bathroom floor. The lower perimeter beam is used as the door border; (9) the terrace is made with a size of $2.00 \mathrm{~m}$ x $0.80 \mathrm{~m}$; (10) ceramic floor size $40 \times 40 \mathrm{~cm}$ is used on the terrace; (11) ceiling mounted from the door frame head (door in the living room). Straightness of the ceiling can also be obtained from the frame head (main door); (12) weighing installation of the ceiling. The artisan hose is used to get the ceiling line; (13) the height of the frame head and the upper perimeter beam are $1.30 \mathrm{~m}$ in size, so that the ceiling height line can be made. The ceiling height can be measured from the lower perimeter head. The height of the wall is $3.20 \mathrm{~m}$ and the ceiling can be installed $20 \mathrm{~cm}$, so the height of the wall becomes $3.00 \mathrm{~m}$; 14) ceiling coverings and ceiling frames adapted to the needs of residents of the house.

\subsection{Economic Considerations $1.14 \%$}

\subsubsection{Coloumn}

Making columns obtained by vernacular architects economic considerations, as follows: (1) column stirrup iron made with a length of $6-10 \mathrm{~cm}$ and a width of $6-10 \mathrm{~cm}$; (2) column stirrups are made of triangular shapes; (3) column stirrup iron is arranged and given a mixture of concreting, so that the column size becomes 10-12 cm; (4) column stirrup iron spaced 30$40 \mathrm{~cm}$; (5) $6 \mathrm{~mm}$ iron and concrete tie wire used as stirrup iron working material; (6) stirrup columns made smaller than the width of the red stone. The column brace is adjusted to the height of the house. This is intended so that column stirrups, lower beam (sloof), and upper perimeter beam (ring beam) when wrapped with plaster look flat and aesthetic. The column appears to appear between the pairs of red stones. It is feared that the column is easily porous and broken; (7) the column is given a mixture of concreting. Sand material is used from the Nambo area. This sand material contains a lot of soil.

\subsubsection{Wall}

Making walls is obtained by vernacular architects economic considerations, as follows: (1) wall plaster made of mortar. Mortar is made with a composition of 1: 4 (1 sack of cement: 3 sand lorries). The sand material uses the composition of 3 Pohara sand lorries and 1 Nambo sand lorry; (2) a skim coat is used with the composition of one bucket of plamir (not soaring) mixed with half a bucket of water. Skim coat can also be used with a composition of eight hand-held plamirs mixed with half a bucket of water and stirred evenly; (3) the outer wall is 
not given a skim coat; 4) sills used in the type of red wood material and included in class II (Two) wood.

\subsubsection{Upper Perimeter Beam (Ring beam)}

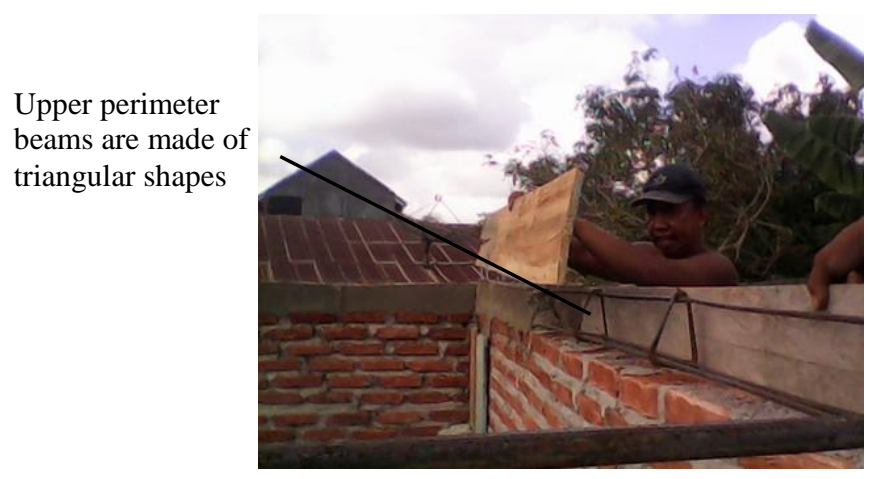

Figure 2. The upper stirrup iron beam is made of a triangle.

The production of upper perimeter beams is obtained by vernacular architects economic considerations, as follows: (1) stirrup iron upper perimeter beam cut per $30 \mathrm{~cm}$. Stirrup iron upper perimeter beam is made from $7-8 \mathrm{~cm}$ long and $7-8 \mathrm{~cm}$ wide. stirrup made triangular shape (figure 2). Concretion of the upper perimeter beam is made with $1-2 \mathrm{~cm}$ thick, so that it can wrap the upper perimeter beam and wall; (2) upper perimeter beams iron is adjusted to the size of the building area.

\subsubsection{Floor}

The making of the upper perimeter beam (ring beam) is obtained by vernacular architects of economic considerations, as follows: (1) sand material is spread over the embankment (heap sand). Material of embankment sand is spread not too thick; (2) embankment sand should be watered so that the mortar does not dry quickly. If the sand is not doused with water, the mortar is feared to quickly drop down; (3) sand embankment material used Nambo sand.

\section{Conclussion}

Based on the description above it can be concluded that the vernacular architect in making the middle structure of a simple building, as follows: in the first stage is careful consideration, in the second stage is a practical consideration, and in the third stage is an economic consideration.Stirrup iron made triangular shape. This research can be continued to test the bending strength of the triangle stirrup.

\section{References}

[1] Martana, S., P.: Problematika Penerapan Metode Field Research Untuk Penelitian Arsitektur Vernakular Di Indonesia. Jurnal Dimensi Teknik Arsitektur, Vol. 34, No. 1, pp. 62, 2006.

[2] Sahroni, A.: Arsitektur Vernakular Indonesia: Peran, Fungsi, dan Pelestarian di Dalam Masyarakat. Jurnal Puslitbang Arkenas - academia.edu, pp. 1, 2012. 
[3] Suharjanto, G.: Membandingkan Istilah Arsitektur Tradisonal Versus Arsitektur Vernakular: Studi Kasus Bangunan Minangkabau dan Bangunan Bali. Jurnal Com Tech, Vol. 2, No. 2, pp. 592-602, 2011.

[4] Handayani, S.: Penerapan Metode Penelitian Participatory Research Apraisal Dalam Penelitian Permukiman Vernakular (Permukiman Kampung Kota). In: Proceeding Seminar Nasional Penelitian Arsitektur-Metoda dan Penerapannya Seri 2, Undip Semarang, pp.1, 2009.

[5] Sehonanda, O., Pandeleke, R., R., Ointu, B., M., M., Tamboto,W., J.: Kajian Uji Laboratorium Nilai Modulus Elastisitas Bata Nerah Dalam Sumbangan Kekakuan Pada Struktur Sederhana. Jurnal Sipil Statik, Vol. 1, No. 12, pp.797-800, 2013.

[6] Purwanto, L., M., F., Gayatri, C., S.: Arsitektur Vernakular Nabire dan Kondisi Nabire Pasca Gempa. Jurnal Dimensi Teknik Arsitektur, Vol. I, No. 1, pp. 22, 2007.

[7] Faisal, G., Wihardyanto, D.: Studi Tata Ruang Rumah Tinggal Suku Talang Mamak (Spatial Study Talang Mamak Tribe House). Jurnal Tesa Arsitektur, Vol. XII, No. 2, p. 98, 2014.

[8] Yustisia, H., Putri, P., Y., Apdeni, R., Sandra, N.: Program Pelatihan kepada Tukang Lokal dalam Rekonstruksi Rumah Pasca Gempa pada Nagari-Nagari di Kabupaten Pasaman. In: Prosiding Konvensi Nasional Asosiasi Pendidikan Teknologi dan Kejuruan (Aptekindo) ke-7 FPTK Universitas Pendidikan Indonesia, Bandung, p.13-14, 2014.

[9] Luthfiah, F., Amir, Martini,: Peningkatan Keahlian Tukang dan Buruh Bangunan dalam Membangun Rumah Sederhana Aman Gempa di Kota Palu. Jurnal Mektek, Vol. XV, No. 1, pp. 10-11, 2013.

[10] Atmaja, J.: Hubungan Faktor Sosial Ekonomi Dengan Kondisi Fisik Bangunan Rumah Tidak Sehat Di Kecamatan Lubuk Alung. Jurnal Ilmiah R \& B, Vol. 4, No. 2, pp. 8, 2004.

[11] Wastika, D., N.: Penerapan Konsep Tri Hita Karana Dalam Perencanaan Perumahan di Bali. Jurnal Permukiman Natah. Jurnal Permukiman Natah, Vol. 3, No. 2, pp. 62-105, 2005.

[12] Rinaldi, Z., Purwantiasning, A., W., Nur'aini, R., D.:Analisa Konstruksi Tahan Gempa Rumah Tradisional Suku Besemah di Kota Pagaralam Sumatera Selatan. In: Seminar Nasional Sains dan Teknologi (Semnastek), Fakultas Teknik Universitas Muhammadiyah Jakarta, 17 November 2015, pp. 2, 2015.

[13] Rantung, C., M., Windah, R., S., Sumajouw, M., D.: Evaluasi Balok dan Kolom pada Rumah Sederhana. Jurnal Sipil Statik, Vol. 2, No. 6, pp. 301-309, 2014.

[14] Sabaruddin, A.: Membangun Rumah Sederhana Sehat Tahan Gempa. Penebar Swadaya, Jakarta, 2008.

[15] Mashuri,: Perwujudan Kosmologi Pada Bangunan Rumah Tradisional Toraja. Lanting Journal of Architecture, Vol. 1, No. 1, pp. 2, 2012.

[16] Iswanto, D.: Kajian Terhadap Struktur Rangka Atap Kayu Rumah Tahan Gempa Bantuan P2KP. Jurnal Enclosure, Vol. 6, No. 1, pp. 10, 2007. 